\title{
The Effectiveness of Using the Sociodrama Method in Efforts to Improve Speaking Skills In Elementary School Students
}

\author{
1st Anton Herman Suyitno, 2nd Yahya Sudarya, 3rd Baharudin akhmad, 4th Sudibya \\ Santosa, 5th Fariz Budiarto \\ \{antonherman94@gmail.com1, yahyasudarya@gmail.com2, \\ baharudin.fortuner@gmail.com3, masdieb@gmail.com 4, farizhheroscout@gmail.com 5\} \\ Master of Basic Education, University of Muhammadiyah Purwokerto, \\ Jl KH Ahmad Dahlan, Banyumas 53182, Indonesia
}

\begin{abstract}
The purpose of this study is to see how the sociodrama method affects the speaking skills of fourth grade elementary school students. A quantitative research method was used in this study. This study's participants were 30 fourth-grade students from SDN 1 Gunungwuled. An action test is used to collect data. According to the findings of research and literature studies from various studies and journal articles, using the sociodrama learning method on students' speaking skills can improve student learning achievement. According to the findings of the study, the average value of each aspect of intelligence has increased. The average student intelligence score ranges from 52.8 percent to 63.6 percent. This means that there are significant differences in speaking skills between students who are taught using the sociodrama learning method and students who are taught using traditional methods in elementary schools.
\end{abstract}

Keywords: Sociodrama Method, Speaking Skills, Elementary School

\section{Introduction}

Teaching is no longer an effort to convey knowledge but also an effort to create a learningenvironment so that teaching goals can be achieved optimally. The quality of teaching depends on choosing the right strategy, especially in an effort to develop students' creativity and attitudes. Therefore, the professional ability of teachers to manage teaching programs with teaching and learning strategies must be developed and fostered. A teacher is required to be able to use various methods in learning, so that learning takes place actively and interestingly. In fact, in Indonesian lessons, especially in acquiring vocabulary and speaking skills, students only stand in front of the class to speak, for example telling stories or giving speeches. While the other students were asked to listen. As a result, teaching speaking is less interesting.

The sociodrama method in Indonesian speaking skills is one method that can help someone in mastering language skills. This method is widely used because in addition to being easy to practice, it can also provide great benefits. The use of the sociodrama method is the right way for students to learn and practice speaking by expressing feelings through movements and facial expressions, so that students' speaking skills are gradually increasing.

The aims of this study are 1.To find out the application of the sociodrama method in improving speaking skills in Indonesian subjects 2. To find out the effectiveness of the use of the sociodrama method in improving Indonesian speaking skills in Class IV at SD Negeri 1 Gunungwuled.

In the 2013 curriculum, Indonesian language learning emphasizes text-based learning. Text-based language learning is learning that allows students to master and use these types of 
texts in society. It is closely related to language skills, namely listening, speaking, reading, and writing skills [1].

In the teaching and learning process we recognize various teaching methods, but not allof these methods can be used in SD/MI, considering the stages of child development, there are several methods that are most dominantly used in carrying out learning [2], namely: (1) Lecture; (2) Questions and Answers; (3) Discussion; (4) Storytelling; (5) Recitation; (6) Experimental; (7) Demonstration; (8) Discovery-inquiry; (9) Field trip; and (10) Sociodrama method.

One of the language skills possessed by a person is speaking skill. Speaking skills are commonly used to communicate in everyday life. A person is said to have speaking skills if the person concerned is skilled at choosing language sounds (in the form of words, sentences, as well as pressure and tone) appropriately and formulating them appropriately in order to convey thoughts, feelings, ideas, facts, actions in a communication context [3].

Speaking skill is a skill in conveying messages through spoken language. This study emphasizes oral language skills or speaking in the form of playing a role that describes social behavior in fifth grade students at SDN Tamansari 1 Bondowoso [4].

Listening and speaking are complementary skills, they are interdependent. There is nothing to say if no one is listening and although we may be able to hear the singing, spoken communication is the main thing to listen to. Listening and speaking are oral language skills, both of which require encoding and re-encoding of oral symbols [5].

In speaking one must use pronunciation, intonation, pause. Pronunciation is a way for people or groups of people to pronounce the sounds of a language. Intonation is a song sentence or the speed of presentation of high and low notes. Pause is a time to stop or pause [6]. One aspect of language that must be mastered by students is speaking, because speaking skills support other skills [7].

One of the learning methods that is considered capable of improving students' speaking skills is the sociodrama method. The sociodrama or simulation method is linguistically derived from the word simulate which means to pretend or act as if and also from the word simulation which means to imitate or act pretending. One of the advantages of the sociodrama method is that the spoken language of students can be fostered. be a good language so that it is easily understood by others [8].

Sociodrama is a role-playing learning method to solve problems related to social phenomena, problems involving human relationships such as juvenile delinquency, drugs, authoritarian family images, and so on. Sociodrama is used to provide understanding and appreciation of social problems and develop students' ability to solve them [9].

The sociodrama method is a teaching method used to describe, act, demonstrate, dramatize, demonstrate behavior, body and facial movements, about problems of social relations between humans so as to achieve certain learning objectives [10].

The application of the sociodrama method in Indonesian lessons is very important because by using this sociodrama method students will develop their speaking skills and can practice expressing ideas or criticisms of what they hear from each scene in the application of the sociodrama method. Teaching Indonesian aims to make students able to use Indonesian to communicate [11].

Speaking is conveying or expressing messages / information, opinions, and expressing feelings to others by using clear language so that the message conveyed can be understood by the other person. [12]. This is the second language activity carried out by humans in language life, namely after listening activities. Based on the sounds that are heard, then humans learn to pronounce and finally become skilled at speaking. Then, learning the role playing method can 
also be used to stimulate students' creativity to express, be confident, and learn to communicate in public, so as to encourage the teaching and learning process. [13].

Based on the description above, it can be concluded that someone who does speaking activities in addition to communicating also aims to influence other people with the intention of what is being discussed can be accepted by the other person well. The existence of an active reciprocal relationship in speaking activities between speakers and listeners will shape communication activities to be more effective and efficient.

With the sociodrama method in learning speaking skills, fourth grade students of SDN 1 Gunungwuled will be able to develop their intellectual, social, and emotional potential, so that later students will be able to communicate and interact socially in a mature, wise, and mature manner.

\section{Research Method}

This study aims to determine the effectiveness of the sociodrama method on Indonesian speaking skills at SD Negeri 1 Gunungwuled, Purbalingga. The interviewed subject is 30 students, and 20 students to get data and conduct research. Every learning activity needs to be assessed including in learning speaking activities.

The method used to determine the extent to which students are able to speak is the speaking ability test. In principle, speaking skills exams provide opportunities for students to speak, not write, so speaking skills assessment is more focused on speaking practice.

Assessment of speaking ability in language teaching is based on two factors, namely linguistic and non-linguistic factors. Linguistic factors include pronunciation, vocabulary, and structure while non-linguistic factors include material, fluency and style [14].

The data collection instrument is a tool for researchers in collecting data. The types of data collection instruments used are: 1. Observation Guide is a guide that contains statements that get certainty through direct observation. 2. Documentation Notes. Documentation of the origin of the word document, which means written goods. In carrying out the documentation method, researchers investigate written objects such as books, magazines, documents, regulations, meeting minutes, diaries, and so on. 3. The test is used to assess the ability to speak Indonesian in Grade IV of SD Negeri 1 Gunungwuled.

The data collection technique is a method used to manage the data that has been collected. The data collection techniques used are as follows: 1. Observation is a data collection method used by direct observation of the research object. The data observed were data about the learning situation at the time of classroom action research using the Sociodrama method. 2. Documentation comes from the word document, which means written goods. 3. Study result test.

The place used for the study was SDN 1 Gunungwuled, Rembang District, Purbalingga Regency. The subjects of the research were 30 elementary school students with 20 male students and 10 female students.

Data management in this study was carried out after the data was collected, then analyzed quantitatively and qualitatively. For quantitative analysis, descriptive analysis is used, namely the average score obtained from the test results for each cycle which aims to determine the level of mastery of the material through the description of the distribution characteristics of learning outcomes using the Sociodrama method which consists of the average value (mean), the highest (maximum) and lowest (minimum).

In connection with sociodrama, Piaget, a psychologist, said that children have an inherent need to learn. This study uses data collection and data analysis methods because after the 
necessary data has been collected, data analysis is needed, namely concluding the data findings to get a precise and accurate result. The nature of this analysis is in the form of an in-depth discussion of the content of the discussion and the aspects assessed.

\begin{tabular}{|l|l|l|lllll|l|}
\hline No & \multicolumn{1}{|c|}{ Assessed ability } & \multicolumn{5}{|c|}{ Scale } & Information \\
\hline $\mathbf{1}$ & Pronunciation & 5 & 4 & 3 & 2 & 1 & \\
\hline $\mathbf{2}$ & Vocabulary & 5 & 4 & 3 & 2 & 1 & \\
\hline $\mathbf{3}$ & Kateri & 5 & 4 & 3 & 2 & 1 & \\
\hline $\mathbf{4}$ & Smooth & 5 & 4 & 3 & 2 & 1 & \\
\hline $\mathbf{5}$ & Style & 5 & 4 & 3 & 2 & 1 & \\
\hline & Amount & & & & & & \\
\hline
\end{tabular}

\section{Results and Discussion}

The results of this study began with interviews, observations, documentation, and tests.

\subsection{Interview}

Interviews were used to find out information on the effectiveness of students' speaking.Interviews were conducted on fourth grade teachers before and after learning Indonesian with a focus on speaking skills using the Sociodrama method. Interviews were conducted before learning was conducted to obtain data about the teaching methods that have been used by teachers in learning Indonesian, to find out the obstacles often faced by teachers and students in the learning process, especially students' speaking skills, student learning outcomes before the research was held, and student activities in the learning process. . Interviews with teachers were conducted after learning aimed at knowing the responses and observations of classroom teachers regarding learning Indonesian with the sociodrama method.

\subsection{Observation}

Observations were made to determine whether there was a match between planning and implementing activities. The things observed in the observation include the activities of teachers and students during the learning process. Observation activities are carried out based on the provisions of the observation sheet provided by placing a checklist $(\square)$ on the aspects of teacher and student indicators.

\subsection{Documentation}

The data taken through the documentation stage includes a list of students' names, the schedule for the implementation of Indonesian language learning, and a list of students' grades in learning Indonesian. Student score data is used as a comparison in improving learning outcomes before and after applying the sociodrama method to Indonesian language learning with a focus on speaking skills.

\subsection{Test}

The test was conducted to determine the students' speaking skills using the sociodrama method. The test was carried out to determine students' speaking skills in role playing by applying the sociodrama method in front of the class in groups. This test refers to the assessment of linguistic and non-linguistic aspects. The linguistic aspects include word choice, accuracy of the target of speech, and accuracy of speech. The non-linguistic aspects assessed include courage, loudness, fluency, intonation, expression, and movement. 
Data management in this study was carried out after the data was collected, then analyzed quantitatively and qualitatively. For quantitative analysis, descriptive analysis is used, namely the average score obtained from the test results for each cycle which aims to determine the level of mastery of the material through the description of the distribution characteristics of learning outcomes using the Sociodrama method which consists of the average value (mean), the highest (maximum) and lowest (minimum). Then the values are grouped by looking at the categorization guidelines. [15].

Table 1. Categorization of Students' Learning Outcomes Mastery Levels

\begin{tabular}{|c|c|}
\hline Value interval & Qualification \\
\hline $85-100$ & Very high \\
\hline $65-84$ & Tall \\
\hline $55-64$ & Currently \\
\hline $45-54$ & Low \\
\hline$\leq 45$ & Very low \\
\hline
\end{tabular}

Meanwhile, to determine student learning completeness by looking at table 2, the Minimum Completeness Criteria Category (KKM) that has been set by the school. This is based on the regulations set by the Minister of National Education Regulation No. 20 of 2007.

Table 2. Categories of Minimum Completeness Criteria (KKM)

\begin{tabular}{|c|c|}
\hline Absorption of Learners & Category Complete Learning \\
\hline $0-64$ & Not finished \\
\hline $65-100$ & Complete \\
\hline
\end{tabular}

Researchers carry out the learning process through the application of the sociodrama method. First of all, the teacher invites students to go to the object that will be used as drama material, before students apply this sociodrama method, the teacher first explains and determines how students learn in carrying out the learning process using this sociodrama method. The next step is that students are divided into several groups and each group consists of 5 students and each group is facilitated by the teacher with drama text sheets containing stories of heroes in their learning activities. Then each group studied the drama text that had been distributed by the teacher. After being studied well, each group went forward and practiced the hero stories in the text that had been given by the teacher. Researchers who in this case also act as teachers observe the course of learning in the classroom and explain if students do not understand and have difficulty in the learning process. Furthermore, students in their groups tell the results of learning to complete and understand the material being studied [16].

The speaking skill text is the speaking skill in Indonesian which includes linguistic aspects which include: accuracy of information, relationship between inflation, accuracy of structure and vocabulary, and reasonableness of the sequence of discourse. While the nonlinguistic aspects include: fluency, pronunciation style. The speaking test is carried out by means of students speaking in Indonesian with the theme of "giving advice" so that at that time the achievement of speaking skills can be known. Aspects assessed in Indonesian speaking skills using the sociodrama method. The assessment used to measure students' speaking ability was done through storytelling tasks. To evaluate students' speaking ability, a speaking assessment 
format is needed. The following is a speaking/story-telling assessment format modified from Jakovits and Gordon's assessment. [17].

Table 3. Scoring and Assessment Criteria

\begin{tabular}{|c|c|c|c|}
\hline No & Rated aspect & \multicolumn{2}{|c|}{ Score Range } \\
\hline 1 & Information Accuracy & $\begin{array}{ll}\text { a. } & \text { Very bad } \\
\text { b. } & \text { Enough } \\
\text { c. } & \text { Accurate }\end{array}$ & $\begin{array}{c}4 \\
7 \\
10\end{array}$ \\
\hline 2 & $\begin{array}{l}\text { Relationship between } \\
\text { information }\end{array}$ & $\begin{array}{ll}\text { a. } & \text { The least } \\
\text { b. quite a bit } \\
\text { c. Full }\end{array}$ & $\begin{array}{c}4 \\
7 \\
10 \\
\end{array}$ \\
\hline 3 & $\begin{array}{l}\text { Structural accuracy and } \\
\text { vocabulary }\end{array}$ & $\begin{array}{ll}\text { a. } & \text { Not exactly } \\
\text { b. } & \text { enough Exactly } \\
\text { c. } & \text { Precisely }\end{array}$ & $\begin{array}{c}4 \\
7 \\
10 \\
\end{array}$ \\
\hline 4 & Smoothness & $\begin{array}{l}\text { a. stammering } \\
\text { b. Smooth enough } \\
\text { c. Very smooth }\end{array}$ & $\begin{array}{c}4 \\
7 \\
10\end{array}$ \\
\hline 5 & $\begin{array}{l}\text { The reasonableness of } \\
\text { the order of discourse }\end{array}$ & $\begin{array}{ll}\text { a. } & \text { Abnormal } \\
\text { b. } & \text { Enough } \\
\text { c. } & \text { Normal } \\
\end{array}$ & $\begin{array}{c}4 \\
7 \\
10 \\
\end{array}$ \\
\hline 6 & Pronunciation style & $\begin{array}{ll}\text { a. } & \text { Rigid } \\
\text { b. } & \text { Enough } \\
\text { c. } & \text { Reasonable } \\
\end{array}$ & $\begin{array}{c}4 \\
7 \\
10\end{array}$ \\
\hline & Total score & & 60 \\
\hline
\end{tabular}

(Nurgiyantoro, 2001: 288)

Based on the assessment criteria above, which are carried out in our school, it can be seen that the activity of students has increased every cycle, from cycle I to cycle II by $20.6 \%$. The results of observing the activities of students in the first cycle of the first meeting obtained a percentage value of $49.4 \%$ and in the first cycle of the second meeting the percentage value was $56.2 \%$ and an increase of $6.9 \%$ The average of the two observations was $52.8 \%$. And the success criteria indicate that the level of activity is still lacking in the Indonesian language learning process through the application of the sociodrama method as

In the activity of observing the activities of students in the second cycle of the first meeting, the percentage value of $68.6 \%$ was obtained and the second cycle of the second meeting was obtained the percentage value of $80 \%$ and an increase of $11.4 \%$. The average of the two observations is $63.6 \%$ and the success criteria indicate that the level of activity is already high in the Indonesian language learning process through the application of the sociodrama method as a learning method. Based on the results of the recapitulation, it shows that there is an increase in the average percentage of student activity in each cycle.

Students enjoy participating in learning speaking skills in this role play. Students are very enthusiastic about participating in learning. In addition, students also feel great benefits from learning speaking skills through the sociodrama method. The benefits obtained include students gaining experience and students also having the courage to speak in public, whether in official or not. Students can also measure the level of their speaking skills (self-reflection), can use this learning as a means to practice public speaking skills in formal situations, and create togetherness among students by working together in groups. This shows that through the 
application of the sociodrama method as a learning method, it has succeeded in increasing students' learning activities in learning Indonesian.

The results showed that the application of the sociodrama method in learning Indonesian in class IV at SDN 1 Gunungwuled could be implemented well. This is proven in each cycle of indicators can be achieved properly as expected. The average obtained from cycle 1 to cycle II In the application of the sociodrama method the percentage increases, this proves that the application of the sociodrama method can improve students' speaking skills. It can be seen from the average result of speaking skills in Cycle I 52.8\%. increased to 63.6\%. In students' speaking skills there was an increase with $10.8 \%$.

\section{Conclusion}

The results of observations of the application of the socio-drama method in cycle I and cycle II have increased. Based on the results of the recapitulation, it shows that there is an increase in the average percentage of student activity in each cycle. Thus, this sociodrama learning method is expected to change the monotonous learning pattern and be able to improve students' speaking skills. Students not only excel in material grades, but also have good speaking skills. The application of the sociodrama method can improve students' speaking skills in Indonesian subjects, the subject of which is playing drama characters. For this reason, it is recommended that teachers use the sociodrama method to be used as a reference for learning methods in improving speaking skills.

\section{References}

[1]. Ramadania F. Konsep bahasa berbasis teks pada buku ajar kurikulum 2013. Stilistika: Jurnal Bahasa, Sastra, dan Pengajarannya. 2016 Oct 1;1(2). https://www.stkipbjm.ac.id/mathdidactic/index.php/STI/article/view/372

[2]. Widiastiti NL, Sumantri M. Model Quantum Teaching Berbasis Pendidikan Karakter Terhadap Motivasi Belajar IPA. Jurnal Pedagogi dan Pembelajaran. 2020 Jul 24;3(2):30314.

[3]. Tambunan P. Pembelajaran keterampilan berbicara di sekolah dasar. Jurnal Curere. 2018 Jul 5;2(1). $\quad$ http://portaluniversitasquality.ac.id:5388/ojssystem/index.php/ CURERE/article/view/109

[4]. Putu Widyantari IA. Peningkatan Keterampilan Berbicara Melalui Metode Sosiodrama $\begin{array}{llllll}\text { pada Siswa Kelas } & \text { V } & \text { SDN } & \text { Tamansari } 1 & \text { Bondowoso. }\end{array}$ https://repository.unej.ac.id/handle/123456789/86087

[5]. January DO. Peningkatan Keterampilan Berbicara dengan Metode Sosiodrama ada Mata Pelajaran Bahasa Indonesia Kelas V di SDN Tegalrejo 02 Kecamatan Tengaran Kabupaten Semarang Tahun 2013 (Doctoral dissertation, IAIN Salatiga). http://erepository.perpus.iainsalatiga.ac.id/74/

[6]. SUSANTO HP. PENERAPAN METODE SOSIODRAMA UNTUK MENINGKATKAN KEMAMPUAN BERBICARA PADA SISWA KELAS V DI SDN ANTIROGO 04 JEMBER. https://repository.unej.ac.id/handle/123456789/79469

[7]. Akmansyah M. Teknik Pengajaran Keterampilan Berbahasa. Al-Bayan. 2011;3(1). http://repository.radenintan.ac.id/811/1/(2011)_Al_Bayan_Vol_3_No_1. Teknik_Pengaj aran_Keterampilan_Berbahasa.pdf

[8]. Djamarah SB, Zain A. Strategi belajar mengajar. Jakarta: Rineka Cipta. 2006 
[9]. Sanjaya W. Educational Process Standards Oriented Learning Strategy. Jakarta: Prenada. 2009.

[10]. Wati UE. Penggunaan Metode Sosiodrama dalam Peningkatan Pembelajaran Bahasa Indonesia bagi Siswa Kelas V SD. KALAM CENDEKIA PGSD KEBUMEN. 2013 May 17;4(2). https://jurnal.fkip.uns.ac.id/index.php/pgsdkebumen/article/view/2059

[11]. Susiati. Metode Pengajaran Bahasa Indonesia. Metode Sosiodrama. 2020. osf.io

[12]. Qarimah WN. Pengaruh Penggunaan Metode Sosiodrama Terhadap Keterampilan Berbicara dalam Mata Pelajaran Bahasa Indonesia Peserta Didik Kelas V MIN 6 Bima Kecamatan Bolo Kabupaten Bima (Doctoral dissertation, Universitas Islam Negeri Alauddin Makassar). http://repositori.uin-alauddin.ac.id/13345/

[13]. Hajjin Mabrur MS, Alirahman AD, Purwati R, Gufron IA. Efektivitas Metode Role Playing Dalam Peningkatan Keterampilan Berbicara pada Mata Pelajaran Bahasa Indonesia di SD Negeri 1 Banjarwangunan Kabupaten Cirebon. http://repository.bungabangsacirebon.ac.id/xmlui/handle/123456789/397

[14]. Haryadi. Berbicara (Pengantar) Diktat Kuliah: IKIP Yogyakarta. 1997.

[15]. Arikunto S. Dasar-dasar Evaluasi Pendidikan. Jakarta : Bumi Akasara. 2005.

[16]. Safitri R. Penerapan Metode Sosiodrama dalam Meningkatkan Aktivitas Belajar Peserta Didik Kelas Vc Mata Pelajaran Bahasa Indonesia di MIN 6 Ulum Sukamaju Kecamatan Jatiagung Lampung Selatan Tahun Ajaran 2016/2017 (Doctoral dissertation, UIN Raden Intan Lampung). http://repository.radenintan.ac.id/1528/

[17]. Nurgiyantoro B. Penilaian dalam pengajaran bahasa dan sastra. BPFE-Yogyakarta; 2001. 